\title{
Antimicrobial Efficacies, Antioxidant Activity and Nutritional Potentials of Trachyspermum ammi
}

Waseem Hassan*, Hamsa Noreen, Shakila Rehman and Shehnaz Gul

Institute of Chemical Sciences, University of Peshawar, Peshawar, Khyber Pakhtunkhwa, Pakistan

*Corresponding author: Waseem Hassan, Institute of Chemical Sciences, University of Peshawar, Peshawar -25120, Khyber Pakhtunkhwa, Pakistan, Tel: 92-91-921665; E-mail: Waseem_anw@yahoo.com

Rec date: Oct 31, 2016; Acc date: Nov 15, 2016; Pub date: Nov 18, 2016

Copyright: (c) 2016 Hassan W, et al. This is an open-access article distributed under the terms of the Creative Commons Attribution License, which permits unrestricted use, distribution, and reproduction in any medium, provided the original author and source are credited.

\begin{abstract}
Trachyspermum ammi (TA) is a traditional medicinal plant which can be considered as a source of natural antioxidants and can be used for a wide range of infectious diseases. Our objectives were to explore the biochemical efficacies of the aqueous and acetonic extract of TA with special emphasis on antimicrobial and antioxidant activities. Nutritional profile and phytochemical screening were performed by standard methods. The agar well diffusion method was used to assess the antimicrobial activity against ten (10) clinical bacterial strains and five (5) fungal stains. The free radical scavenging activity of the acetonic extract was estimated spectrophotometrically by the 2, 2-diphenyl-1-picrylhydrazyl (DPPH) assay. In seeds of TA, the crude fat, crude fiber, vitamin $\mathrm{C}$, moisture, ash contents, crude protein, TSS, total acidity, $\mathrm{pH}$ and total sugar were $4.6 \pm 0.19 \%, 4.2 \pm$ $0.1 \%, 13.5 \pm 0.7 \%, 9.5 \pm 0.19 \%, 11.5 \pm 1.7 \%, 1.46 \pm 0.2 \%, 1.1 \pm 0.01 \%, 0.65 \pm 0.01 \%, 5.75 \pm 0.9 \%$ and $5.1 \pm 0.9 \%$ respectively. TA tested positive for alkaloids, carbohydrates and sugar, phenolic compounds, flavonoids, protein and amino acid, gum and mucilage and tannins, while negative results were found for saponins. Antioxidant assessments by DPPH assay showed that acetonic extract of TA possess high radical-scavenging activity i.e., 71.0 $\pm 2.3 \%$. Vitamin $\mathrm{C}$ was used as reference standard. Susceptibility testing of acetonic extract of $T A$ revealed strong antibacterial activity against Staphylococcus aureus (zone of growth inhibition $13 \mathrm{~mm}$ ), good activity against Salmonella typhi and Xanthomonas (with zone diameter of $12 \mathrm{~mm}$ ), while TA was least active against Salmonella heidelberg (inhibition zone diameter of $5 \mathrm{~mm}$ ), Klebsiella pneumoniae and Clostridium with $6 \mathrm{~mm}$ zone of inhibition. TA also exhibited maximum antifungal activity against Aspergillus niger $(15 \mathrm{~mm})$ and Entomola $(11 \mathrm{~mm})$. While least activity was observed against $A$. flavus and Alternaria alternata (inhibition zone diameter of $9 \mathrm{~mm}$, each). Based on the experimental data, TA could be considered as a therapeutic agent to inhibit the free radical-mediated reactions in biological systems. However further molecular studies and mechanistic insights are needed.
\end{abstract}

Keywords: Trachyspermum ammi; Antioxidant; Antimicrobial

\section{Introduction}

Currently researchers are focusing on the assessment of phytomedicines for the detection of bioactive compounds such as tocopherols, carotenoids, ascorbates, polyphenolics and terpenoids which are consumed as alternative therapeutic agents for the treatment of various pathologies [1]. Free radicals are produced as a result of aerobic metabolic processes in cellular membrane, mitochondria, endoplasmic reticulum, peroxisomes, nucleus, lysosomes and cytoplasm, which causes oxidative damage to DNA, proteins, cells (cytotoxicity), nucleic acids, lipids, enzyme inhibition and ultimately leads to cellular death [2].

Various degenerative diseases including stomach disorders, dysentery, scrofula, wounds, skin diseases, urinary tract infections, asthma, piles, sensory and nervous system dysfunctions, inflammatory diseases, rheumatism, kidney troubles, hepatitis, ageing, malarial fevers, typhoid, cardiovascular diseases and immune deficiency diseases, cancer [3] various psychiatric disorders like obsessivecompulsive disorder, social phobia, panic disorder, major depression, posttraumatic stress disorder, Parkinson's disease, autism and Alzheimer's disease are also associated with oxidative stress [4]. Therefore, an antioxidant supplement in daily nutrition is necessary when defensive mechanism of human cells is disturbed.
Trachyspermum ammi (TA) commonly known as Ajowan is an annual herbaceous plant of Umbelliferae family, widely cultivated in different counties such as Pakistan, Egypt, India, Afghanistan, Europe and Iran. The fruit of and TA has approximately 5\% essential oil in its compartments which are important commercial products for food and flavoring industry [5]. Beside these industrial applications, TA have numerous pharmacological properties and various biological activities like anti-inflammatory, antimicrobial, anthelmintic, antihypertensive, antiflatulent, antilithiasis, antispasmodic, analgesic, bronchodilator, hepatoprotective, antiplatelet, insecticidal and spermicidal activities [6,7].

Literature revealed that the functional properties of TA are due to the presence of phenolic compounds i.e., thymol, p-cymene, $\gamma$ terpinene and carvacrol. In other studies carvacrol, $\gamma$-terpinene and $\mathrm{p}$ cymene are reported as major components of Iranian and African ajowan oil, while thymol (97.9\%) is the main component of south India ajowan oil. So, four chemo types, i) carvacrol, thymol; ii) $\gamma$-terpinene, thymol; iii) thymol; iv) $\gamma$-terpinene, carvacrol for TA oil have been studied, which are used for the treatment of lack of appetite, gastrointestinal diseases and bronchial problems. The essential oil also exhibits detoxification of aflatoxins, antimicrobial, fungicidal, antihypertensive and anti-aggregatory effects on humans [8-10].

Considering the vast medicinal significance of TA, phytochemical composition and nutritional profile of aqueous extract of TA was explored. Currently, infection rates have increased and antibiotic 
resistance has developed therapeutic problem [11], therefore the present study was designed to determine the antimicrobial potential of acetonic extract of TA. Furthermore, interest in the antioxidant activity of plant extracts has increased [12] and for the purpose the antioxidant activity of acetonic extract of TA was explored, which would help in the development of novel candidate drugs.

\section{Experimental}

\section{Collection of sample}

The sample of TA was collected in March 2012 from the local market of Peshawar, identified at the PCSIR Laboratory (Khyber Pakhtoonkwha, Pakistan) and kept in polyethylene bags till analysis.

\section{Proximate analysis}

A proximate analysis (vitamin $\mathrm{C}$, moisture, $\mathrm{pH}$, acidity, ash, total soluble solids (TSS), crude fiber, total sugar and protein) of aqueous extract of TA was evaluated using the standard procedures of Association of Official Analytical Chemist [13].

\section{Phytochemical screening}

The qualitative assessment of phytochemical compounds of aqueous extract of TA was carried out for detection of major phytoconstituents (proteins and amino acids, glycosides, flavonoids, phenolic compounds, carbohydrate and sugar, tannins, gum and mucilage and phytosterols) using the standard procedures as described by Association of Official Analytical Chemist [14].

\section{Antimicrobial bioassays}

The antibacterial and antifungal activities of acetonic extract of TA against four gram positive bacteria (Bacillus cereus, Staphylococcus aureus, Clostridium, Bacillus subtilis), six gram negative bacteria (Salmonella typhi, Klebsiella pneumonia, Escherichia coli, Escherichia coli (human), Xanthomonas, Salmonella heidelberg and five fungal stains (Aspergillus niger, Entomola, Aspergillus flavus, Alternaria alternata, Penicillium) were examined by agar well diffusion method [15-17].

\section{Antioxidant activity (DPPH free radical scavenging activity)}

The free radical scavenging activity of acetonic extract of TA was evaluated with 1, 1-diphenyl 2-picryl hydrazyl radical (DPPH) spectrophotometrically at $517 \mathrm{~nm}$. The inhibition curve was plotted for duplicate experiments and represented as \% of mean inhibition \pm standard deviation [18].

\section{Results}

The nutritional profile (carbohydrate, fats, fiber, protein, moisture, ash, TSS, total acidity, $\mathrm{pH}$ and vitamin $\mathrm{C}$ ) of aqueous extract of TA is given in Table 1. The crude fat, crude fiber and vitamin $\mathrm{C}$ observed were $4.6 \pm 0.19 \%, 4.2 \pm 0.1 \%$ and $13.5 \pm 0.7 \mathrm{mg} / 100 \mathrm{~mL}$ respectively. The calculated values for moisture, ash contents and crude protein were $(9.5 \pm 0.19 \%, 11.5 \pm 1.7 \%$ and $1.46 \pm 0.2 \%)$ respectively, while TA also had TSS $(1.1 \pm 0.01 \%)$, total acidity $(0.65 \pm 0.01 \%)$, pH $(5.75 \pm$ $0.9 \%)$ and total sugar $(5.1 \pm 0.9 \%)$. The phytochemicals (alkaloids, flavonoids, glycosides, carbohydrate and sugar, phenolic compound, protein and amino acid, saponins, tannins, gum and mucilage and phytosterols) were detected in aqueous extracts of TA as presented in Table 2. The results of TA indicated that flavonoids, glycosides, carbohydrate and sugar, phenolic compounds, proteins and amino acids, phytosterols, tannins and gum and mucilage were present in the extract while saponins were not found.

\begin{tabular}{|l|l|}
\hline Constituents & Trachyspermum ammi (\%) \\
\hline Crude fats & $4.6 \pm 0.19$ \\
\hline Crude fiber & $4.2 \pm 0.1$ \\
\hline Crude protein & $1.46 \pm 0.2$ \\
\hline Moisture & $9.5 \pm 0.19$ \\
\hline Ash & $11.5 \pm 1.7$ \\
\hline Total soluble solids & $1.1 \pm 0.01$ \\
\hline Total acidity & $0.65 \pm 0.01$ \\
\hline pH & $5.75 \pm 0.9$ \\
\hline Vitamin C & $13.5 \pm 0.7$ \\
\hline Total sugar & $5.1 \pm 0.9$ \\
\hline
\end{tabular}

Table 1: Nutritional profile of aqueous extract of $T A$.

\begin{tabular}{|l|c|}
\hline Phytoconstituents & Trachyspermum ammi \\
\hline Alkaloids & + \\
\hline Saponins & + \\
\hline Carbohydrate and sugar & + \\
\hline Glycosides & + \\
\hline Phenolic compound & + \\
\hline Flavonoids & + \\
\hline Protein and amino acid & + \\
\hline Phytosterols & + \\
\hline Tannins & + \\
\hline Gum and mucilage & + \\
\hline
\end{tabular}

Table 2: Qualitative analysis of the phytochemicals aqueous extract of $T A$.

Antioxidant activities of acetonic extracts of TA, measured at different concentrations $(1-30 \mathrm{mg} / \mathrm{mL})$ are presented in Tables 3 and 4 . The acetonic extract of TA exhibited antioxidant activity with values of $9.28 \pm 0.1 \%, 25.76 \pm 0.9 \%, 35.84 \pm 1.5 \%, 45.47 \pm 1.19 \%, 52.09 \pm 2.0 \%$, $61.17 \pm 1.78 \%$ and $71.0 \pm 2.3 \%$ at $1-30 \mathrm{mg} / \mathrm{mL}$ concentrations. Vitamin $C$ was used as a standard which displayed $38.08 \pm 1.18,53.58$ $\pm 1.16,68.37 \pm 1.15,81.28 \pm 2.45,83.12 \pm 2.78,84.21 \pm 2.54$ and $85.0 \pm$ 2.75 (\%) antioxidant activity at different concentrations i.e., 1-30 $\mathrm{mg} / \mathrm{mL}$. The zone of inhibition of TA and standard streptomycin activity was recorded against different pathogenic bacteria and fungi, summarized in Table 5 and 6 . Results revealed that the extract of TA was effective against all the tested bacteria. TA showed highest zone of inhibition against Staphylococcus aureus $(13 \mathrm{~mm})$, Salmonella typhi 
and Xanthomonas (12 mm). TA also exhibited good activities against Escherichia coli (human) (11 mm), Bacillus subtilis (10 mm), Bacillus cereus and Escherichia coli $(9 \mathrm{~mm})$. But TA was least active against Salmonella heidelberg $(5 \mathrm{~mm})$ and Clostridium with $6 \mathrm{~mm}$ zone of inhibition. The antifungal activity of acetonic extract of TA was also evaluated against five fungal strains (Table 6). The acetonic extract of TA disclosed maximum (15 mm) zone of inhibition against Aspergillus niger, followed by Entomola $(11 \mathrm{~mm})$, Penicillium $(10 \mathrm{~mm})$, Aspergillus flavus and Alternaria alternata $(9 \mathrm{~mm})$.

\section{Discussion}

Aqueous extract of TA has appreciable amount of basic food nutrient as displayed in Table 1. Highest amount of vitamin C (13.5 \pm $0.7 \%)$ shows that TA is a good source of vitamins. Literature exposed that ascorbic acid facilitates the production of collagen, protein, scar tissue, teeth, bone, gums, cartilage, blood vessels and skin. Vitamin C can also fight against the infections and helps in the absorption of minerals [19,20]. Moreover, the high ash content (11.5 $\pm 1.7 \%)$ designates that it could be a rich source of minerals. The plant can highly provide dietary supplements and can lower the rate of coronary heart disease, breast cancer, serum cholesterol level, constipation, hypertension, colon and diabetes [21,22].

Phytochemical screening of TA indicates that flavonoids, glycosides, carbohydrate and sugar, phenolic compounds, proteins and amino acids, phytosterols, tannins and gum and mucilage are present in the extract. However, saponins are not identified in the seeds of TA. These secondary metabolites are known to be biologically active and play a beneficial role in the treatment of different diseases [23]. Moreover, Phytocompounds are also responsible for flavor, color, smell of plants and are important part of a plant's defense system, protect them against vertebrates, herbivorous insect's fungi, parasites and pathogens [24]. Further studies demonstrated that flavonoids are essential bioactive polyphenolic compounds of the plants, play an effective role in controlling various biological activities i.e., anti-angiotec, antiinflammatory, antioxidant, antimicrobial, anti-cholesterol and reduced hypertension [25,26]. Similar to the flavonoids, tannins are also significant phenolic compounds, acting as primary free radical scavengers or antioxidants [27]. However, these are more effective in treating ulcerated and inflamed tissues [28]. Literature exposed the anti-microbial and anti-diarrheal activities of tannins. Besides, terpenoids are also detected in aqueous extract of TA. Terpenoids have the capability to suppress the apoptosis-inducing activity, tumor cell proliferation and can also decreases the cholesterol level and risk of cardiovascular diseases. So, TA has potential as a source of medicine for inhibition and cure of cancer and heart diseases [29]. Results from phytochemical screening confirmed that TA is a potential source of important secondary metabolites.

Organisms have developed complex antioxidant systems against oxidative stress, protecting the main biological membranes i.e., DNA, lipid and proteins from oxidative damage. These antioxidants are either generated in body or derived from nutrients. Consumption of antioxidants rich food has played a significant part in the prevention of neurodegenerative diseases, inflammation, cardiovascular diseases, cancers and problems caused by aging. The antioxidant activity of the plants could be attributed to the presence of phenolic compounds and phytochemical constituents. Mechanistically, they can terminate free radicals by the donation of hydrogen atom or electrons to the oxidized molecule or radicals [30,31]. Therefore, it is vital to evaluate the antioxidant activity of TA.
DPPH is extensively used in biochemical system to explore the antioxidant activity in a very short time compare to other techniques. DPPH is a stable, nitrogen centered free radical, decolorize in the presence of antioxidant at an absorbance of $517 \mathrm{~nm}$. The DPPH antioxidant assay is based on the reduction of purple colored 1,1diphenyl-2-picryl-hydrazyl (DPPH) in the presence of hydrogen donating antioxidants by the production of yellow colored diphenylpicryl hydrazine. The more antioxidant compounds exist in the plant; more will be the reduction of DPPH [32,33]. In addition, our results suggested that the scavenging ability of acetonic extracts of TA also depend on the concentration and expressed as $\mathrm{IC}_{50}$ values shown in Tables 3 and 4, as calculated from the percent inhibition versus the concentration of extract curves. Concentration of the sample necessary to decrease the initial concentration of DPPH by $50 \%\left(\mathrm{IC}_{50}\right)$ under the experimental condition was calculated. TA exhibited significant antioxidant activity i.e., $\mathrm{IC}_{50} 20 \mathrm{mg} / \mathrm{mL}$ whereas the positive control, vitamin $\mathrm{C}$, showed an $\mathrm{IC}_{50}$ value of $04 \mathrm{mg} / \mathrm{mL}$. The high antioxidant of plant extract may be due to the neutralization of free radicals (DPPH), either by transfer of an electron or via transfer of hydrogen atom $[34,35]$. The scavenging ability of the plant against DPPH can be attributed to the presence of bioactive compounds.

\begin{tabular}{|c|c|c|}
\hline Concentration $(\mathrm{mg} / \mathrm{mL})$ & $\begin{array}{l}\text { Trachyspermum ammi } \\
(\%)\end{array}$ & $\begin{array}{l}\text { Vitamin C (Standard) } \\
(\%)\end{array}$ \\
\hline 1 & $9.28 \pm 0.1$ & $38.08 \pm 1.18$ \\
\hline 5 & $25.76 \pm 0.9$ & $53.58 \pm 1.16$ \\
\hline 10 & $35.84 \pm 1.5$ & $68.37 \pm 1.15$ \\
\hline 15 & $45.47 \pm 1.19$ & $81.28 \pm 2.45$ \\
\hline 20 & $52.09 \pm 2.0$ & $83.12 \pm 2.78$ \\
\hline 25 & $61.17 \pm 1.78$ & $84.21 \pm 2.54$ \\
\hline 30 & $71.0 \pm 2.3$ & $85.0 \pm 2.75$ \\
\hline
\end{tabular}

Table 3: DPPH radical scavenging activity of acetonic extract of TA. ${ }^{*}$ mean \pm S.D $(n=3)$.

Medicinal plants produce large number of secondary metabolites which act as protective agents against biotic and abiotic stresses. Several phytochemical compounds have been investigated for their antibacterial activities [36] and their presence in the tested extract could explain its antibacterial effects. The contradictions in bacterial susceptibility to the extract are due to several reasons e.g., microbial strains, concentrations, species of herbs, extraction processes solvents and antimicrobial assessment techniques [37].

\begin{tabular}{|l|l|l|}
\hline S. No. & Acetonic Extracts & IC $_{50}$ value \\
\hline 1 & Trachyspermum ammi & 20 \\
\hline 5 & Vitamin C & 04 \\
\hline
\end{tabular}

Table 4: DPPH radical scavenging activity of acetonic extract of TA $\left(\mathrm{IC}_{50}\right.$ in $\left.\mathrm{mg} / \mathrm{mL}\right)$.

The gram-positive bacteria do not have a periplasmic space and an outer membrane which is found in the gram-negative bacteria. Therefore, in gram positive bacteria the antibacterial substances disrupt the cytoplasmic membrane and bacterial cell wall, resulting in the cytoplasm's leakage and coagulation. While the outer membrane 
of the gram-positive bacteria has lipopolysaccharide rich hydrophilic surface act as a shield against several antibiotic molecules. In addition, the enzymes in the periplasmic space can break the molecules from outside [38]. In our study acetonic extract of TA produced strong inhibitory zones against Staphylococcus aureus, Salmonella typhi and Xanthomonas compared with the standard (Tables 5,6). In this screening, acetonic extract of TA was active against all microorganisms, e.g., gram-negative, gram-positive and fungal strains.

\begin{tabular}{|l|l|c|c|}
\hline S. No & Microorganism & $\begin{array}{l}\text { Inhibition Zone } \\
\text { Diameter }(\mathbf{m m})\end{array}$ & $\begin{array}{l}\text { Streptomycin } \\
\text { (Standard) }\end{array}$ \\
\hline 1 & Salmonella typhi & 12 & 23 \\
\hline 2 & Bacillus cereus & 9 & 15 \\
\hline 3 & Klebsiella pneumoniae & 6 & 14 \\
\hline 4 & Escherichia coli & 9 & 20 \\
\hline 5 & Xanthomonas & 12 & 13 \\
\hline 6 & Salmonella heidelberg & 5 & 15 \\
\hline 7 & Staphylococcus aureus & 13 & 20 \\
\hline 8 & Clostridium & 6 & 23 \\
\hline 9 & Escherichiacoli (human) & 11 & 15 \\
\hline 10 & Bacillus subtilis & 10 & 14 \\
\hline
\end{tabular}

Table 5: Antibacterial activity of acetonic extract of $T A$.

\begin{tabular}{|l|l|c|c|}
\hline S. No & Fungal Strains & $\begin{array}{l}\text { Inhibition Zone } \\
\text { Diameter }(\mathbf{m m})\end{array}$ & $\begin{array}{l}\text { Streptomycin } \\
\text { (Standard) }\end{array}$ \\
\hline 1 & Aspergillus niger & 15 & 9 \\
\hline 2 & Entomola & 11 & 14 \\
\hline 3 & Aspergillus flavus & 09 & 15 \\
\hline 4 & Alternaria alternata & 09 & 10 \\
\hline 5 & Penicillium & 10 & 17 \\
\hline
\end{tabular}

Table 6: Antifungal activity of acetonic extract of $T A$.

\section{Conclusion}

Our data suggest that TA seeds are an excellent source of vitamins which are essential in the human diet. They also contain significant amounts of proteins, dietary fibers and a number of useful phytochemicals such as alkaloids, flavonoids, glycosides, phenolic compounds and tannins etc. which may be responsible for the majority of its pharmacological effects. These bioactive compounds and nutritional rich composition makes it valuable functional food and beneficial nutritional supplements. The high scavenging activity against DPPH suggested it as a potential source as herbal remedy for oxidative stress induced diseases. The acetonic extract of TA also exhibited the strong antimicrobial activity confirming the traditional use of this plant in the treatment of various bacterial infections such as diarrhea and skin diseases. Further studies are needed to explore the toxicological aspects of crude extract/fractions of TA to confirm its medicinal status against various pathological situations.

\section{References}

1. Shabbir M, Khan MR, Saeed N (2013) Assessment of phytochemicals, antioxidant, anti-lipid peroxidation and anti-hemolytic activity of extract and various fractions of Maytenus royleanus leaves. BMC Complement Altern Med 143: 1-13.

2. Hassan W, Noreen H, Castro-Gomes V, Mohammadzai I, Rocha BTDJ, et al. (2016) Association of Oxidative Stress with Psychiatric Disorders. Curr Pharm Des 22: 2960-2974.

3. Hassan W, Rehman S, Noreen H, Gul S, Kazmi SNZ, et al. (2015) Metallic Content of One Hundred Medicinal Plants. J Nutr Disord Ther 5: 1-9.

4. Hassan W, Silva EBC, Mohammadzai IU, Rocha BTDJ (2014) Association of oxidative stress to the genesis of anxiety: implications for possible therapeutic interventions. Curr Neuropharmacol 12: 120-139.

5. Shojaaddini M, Moharramipour S, Sahaf B (2008) Fumigant toxicity of essential oil from Carum copticum against Indian meal moth, Plodia interpunctella. J Plant Prot Res 48: 411-419.

6. Chatterjee S, Goswami N, Kothari N (2013) Evaluation of antioxidant activity of essential oil from Ajwain (Trachyspermum ammi) seeds. Int J Green Pharm 7: 140-144.

7. Raeisi S, Sharifi-Rad M, Quek SY, Shabanpour B, Sharifi-Rad J (2016) Evaluation of antioxidant and antimicrobial effects of shallot (Allium ascalonicum L.) fruit and ajwain (Trachyspermum ammi (L.) Sprague) seed extracts in semi-fried coated rainbow trout (Oncorhynchus mykiss) fillets for shelf-life extension. LWT-Food Sci Technol 65: 112-121.

8. Bairwa R, Sodha R, Rajawat B (2012) Trachyspermum ammi. Pharmacogn Rev 6: 56-60.

9. Singh G, Nagori B (2014) Physicochemical characterization and spasmolytic activity of essential oil of fennel (foeniculum vulgare linn). Inter J Pharmacother 1: 97-103.

10. Vitali LA, Beghelli D, Nya PCB, Bistoni O, Cappellacci L, et al. (2016) Diverse biological effects of the essential oil from Iranian Trachyspermum ammi. Arabian J Chem 9: 775-786.

11. Hassan W, Kazmi SNZ, Noreen H, Riaz A, Zaman B (2016) Antimicrobial Activity of Cinnamomum tamala Leaves. J Nutr Disorders Ther 6: 1-5.

12. Salazar-Aranda R, Perez-Lopez LA, Lopez-Arroyo J, Alanis-Garza BA, Torres WDN (2011) Antimicrobial and antioxidant activities of plants from northeast of Mexico. J Evid Based Complementary Altern Med 45: 493-496.

13. AOAC (2000) Official methods of analysis Association of Official Analytical Chemist, Washington DC. USA.

14. Bauer W, Kirby E, Sherris EM, Turk MM (1996) Antibiotic susceptibility testing by a standardized single disk method. Am J Clin Pathol 45: 493.

15. Olurinola P (1996) A laboratory manual of pharmaceutical microbiology. 69: 1-105.

16. Murray PR, Pfaller MA, Tenover FC, Yolken HR (1995) Manual of Clinical Microbiology (6th edn). ASM Press, Washington DC, pp: 15-18.

17. Aqil F, Ahmad I, Mehmood Z (2006) Antioxidant and free radical scavenging properties of twelve traditionally used Indian medicinal plants. Turkish J Biol 30: 177-183.

18. Godfrey J, Munga J, Andrew D, Akais C, Bonton B, et al. (2014) Proximate composition, Vitamin C and Beta-Carotene Contents of Fifteen Selected Leafy Wild and Semi-Wild Food Plants (WSWFPs) from Bunyoro Kitara Kingdom, Uganda. J Nat Prod Plant Resour 4: 1-12.

19. Akpabio U, Ikpe E (2013) Proximate composition and nutrient analysis of Aneilema aequinoctiale leaves. Asian J Plant Sci Res 3: 55-61.

20. Anyasor GN, Onajobi FD, Osilesi O, Adebawo O (2014) Proximate composition, mineral content and in vitro antioxidant activity of leaf and stem of Costus afer (Ginger lily). J intercult ethnopharmacol 3: 128.

21. Magaia T, Uamusse A, Sjoholm I, Skog K (2013) Proximate Analysis of Five Wild Fruits of Mozambique. The Scientific World Journal 2013: 1-6.

22. Igbinosa O, Igbinosa E, Aiyegoro O (2009) Antimicrobial activity and phytochemical screening of stem bark extracts from Jatropha curcas (Linn). Afr J Pharm Pharacol 3: 058-062. 
Citation: Hassan W, Noreen H, Rehman S, Gul S (2016) Antimicrobial Efficacies, Antioxidant Activity and Nutritional Potentials of Trachyspermum ammi. Vitam Miner 5: 145.

Page 5 of 5

23. McCullough ML, Peterson JJ, Patel R, Jacques PF, Shah R, et al. (2012) Flavonoid intake and cardiovascular disease mortality in a prospective cohort of US adults. Am J Clin Nutr 95: 454-464

24. Balasuriya BWN, Rupasinghe HPV (2011) Plant flavonoids as angiotensin converting enzyme inhibitors in regulation of hypertension. Funct food health dis 1: 172-188.

25. Wani M, Sarvar FA, Agrawal J (2008) Qualitative phytochemical analysis and antimicrobial activity studies of Gymnema sylvestre R. Br. Acta Biol Indica 1: 121-124

26. Ayoola GA, Coker HAB, Adesegun SA (2008) Phytochemical screening and antioxidant activities of some selected medicinal plants used for malaria therapy in Southwestern Nigeria. Trop J Pharm Res 7: 1019-1024.

27. Parekh J, Chanda S (2007) In vitro antibacterial activity of the crude methanol extract of Woodfordia fruticosa Kurz. flower (Lythraceae). Braz J Microbiol 38: 204-207.

28. Goto T, Takahashi N, Hirai S, Kawada T (2010) Various Terpenoids Derived from Herbal and Dietary Plants Function as PPAR Modulators and Regulate Carbohydrate and Lipid Metabolism. PPAR Research, pp: 1-9.

29. Sowndhararajan K, Kang SC (2013) Free radical scavenging activity from different extracts of leaves of Bauhinia vahlii Wight and Arn. Saudi J Biol Sci 20: 319-325.

30. Tacouri DD, Ramful-Baboolall D, Puchooa D (2013) In vitro bioactivity and phytochemical screening of selected spices used in Mauritian foods. Asian Pac J Trop Dis 3: 253-261.
31. Amudha M, Rani S (2016) Evaluation of In Vitro Antioxidant Potential of Cordia retusa. Indian J Pharm Sci 78: 80-86.

32. Nursakinah I, Zulkhairi HA, Norhafizah M, Hasnah B, Zamree MS, et al. (2012) Nutritional content and in vitro antioxidant potential of Garcinia atroviridis (Asam gelugor) leaves and fruits. Malays J Nutr 18: 363-371.

33. Krishna TM, Shiva D, Keerthi D, Nandini A, Aswaq A, et al. (2013) In vitro evaluation of antioxidant properties of Cucumis melo L. extracts of leaves and fruit. Int J Pharm Bio Sci 4: 705-712.

34. Sumathy R, Sankaranarayanan S, Bama P, Ramachandran J, Vijayalakshmi M, et al. (2013) Antioxidant and antihemolytic activity of flavanoid extract from fruit peel of Punica granatum. Asian J Pharm Clin Res 6: 211-214.

35. Ahmed RS, Seth V, Pasha ST, Banerjee BD (2000) Influence of dietary ginger (Zingiber officinales Rosc) on oxidative stress induced by malathion in rats. Food Chem Toxicol 38: 443-450.

36. Weerakkody NS, Caffin N, Turner MS, Dykes GA (2010) In vitro antimicrobial activity of less-utilized spice and herb extracts against selected food-borne bacteria. Food Control 21: 1408-1414.

37. Qabaha KI (2013) Antimicrobial and free radical scavenging activities of five Palestinian medicinal plants. Afr J Tradit Complement Altern Med 10: 101-108.

38. Shan B, Cai YZ, Sun M, Corke H (2005) Antioxidant capacity of 26 spice extracts and characterization of their phenolic constituents. J Agric Food Chem 53: 7749-7759. 